example, it has spread itself too thinly. Sometimes plans which have been broached to the people most dircetly affected have then been put into cold storage for lack of people or money to follow them through. On other occasions the ministry has been downright inconsistent or ambiguous. What, for example, is its policy towards the research associations? What precisely does it mean by the European Technological Community? Then, with the most human frailty, it tends to grasp the thorny nettles last of all-there is, for example, little sign of movement on the reorganization of the nuclear power industry. Elsewhere the ministry's influence, no doubt unwittingly, has been mischievous. Its joyful espousal of the cause of tribology has been indecently innocent. By going out of its way to make technology respectable (which it is), the ministry has cast what it calls pure science in a villain's role and it will be a serious matter if that becomes a permanence.

At this stage nobody can know precisely what the future holds. The Ministry of Technology may have been able to prove the point that governments can usefully play a creative part in industry, but it does not follow that the patterns of administration now being created will last indefinitely. And in many ways, of course, success implies that the ministry will do itself out of a job. Now, for example, that its efforts to weld the British companies in the British motor industry into a single unit have been successful, it is much easier for the ministry to wash its hands of the motor industry's anxieties. By the same test, if and when it rationalizes the computer industry, it will be able to retire graccfully to those sidelines as well. To say this, of course, does not mean that there will be nothing for the ministry to do, but rather that its industrial interests are bound to change frequently with the passing of time. In the circumstances, it is hard to see just what part the ministry's laboratories will play in the continuing future-is there really a need for them? But if it were not for the laboratories, what distinction would there be between the Ministry of Technology and several other agencies of government - the Board of Trade, the Ministry of Power and the Department of Economic Affairs, for example? In other words, although the Ministry of Technology has made a useful start, and although the foreseeable future is crammed with work, it will not be surprising if ten years from now the pattern of administration is radically different from what it is at present. And the test by which it will eventually be judged is whether, like the midwife it should aim to be, it will be prepared to retire gracefully once it has done its obvious job in some sector of British industry. The signs are not always encouraging.

\section{Expensive Nuclear Power}

THE controversy over the way in which British nuclear power plants are built is not being allowed to die a quiet death. Mr Norman Atkinson, Labour Member of Parliament for Tottenham, has tabled a motion in the House of Commons urging the Government to implement the findings of the Select Committee on Science and Technology, of which he was a member. The committee, which produced its report in December 1967, suid that nuclear power stations in Britain should be designed by one large group, taking in all the experience of the existing three consortia and of the Atomic Energy Authority. Mr Atkinson has since resigned from the committee, because, he says, he did not agree that an all party body was the right way for a Labour Government to determine its policy on nuclear power. Despite this, his motion that the recommendations of the select committee be now implemented has been tabled, and has the support of over one hundred Labour Members of Parliament.

$\mathrm{Mr}$ Atkinson is convinced that the way in which the Central Electricity Generating Board has organized the building of power stations has cost Britain $\$ 40$ million. This suspicion arose originally in the proceedings of the select committee, when it emerged that the CEGB had approved a change in the design of the channel diameter between Dungeness $B$ and Hinkley Point $B$, the first two advanced gas cooled reactors to be built. It was claimed that, if this change had not been made, some $£ 11-13$ million could have been saved on Hinkley $B$. Both the CEGB and the Nuclear Power Group, makers of Hinkley $B$, indignantly dismiss the charge, and it is probably fair to say that other members of the select committee were doubtful about it too. Very little was made of it in the report. Mr Atkinson has now extended the same argument, claiming that, if all the first four AGRs had been identical, $f 40$ million could have been saved on the capital cost of $£ 320$ million. "The CEGB commissioned virtual replicas, but did not get the economic saving of replication," Mr Atkinson says. The civil engineering work on all the power stations was also far too expensive-companies from the United States could have done it for half as much.

All this is likely to be taken as just another example of Mr Atkinson's enthusiastic approach to politics. There may well have been mistakes in the arrangements of the first few $A G R s$, but it is very unlikely that they will cost as much as $\mathrm{Mr}$ Atkinson claims. The difference between United States capital costs and British ones is at least as much a function of the design of the reactor system as it is of civil engineering inefficiency. But it is entirely sensible of Mr Atkinson to feel that it is about time the Government made up its mind about the future pattern of nuclear power in Britain. Until the select committee report was published, there was almost an excuse for inaction, but by now the Government can quite properly be accused of indecision. $\mathrm{Mr}$ Atkinson claims that the Government is under pressure from the consortia to retain the existing system-which is doubtless true-and that the CEGR also opposes the single design authority. Even if the Government were not on the point of announcing new nuclear power stations to provide power for aluminium smelters, there would still be no excuse for further delay.

\section{Sites for Nuclear Power}

The British Government clearly intends to build nuclear power stations much nearer to centres of population. In the House of Commons last week, Mr Richard Marsh, Minister of Power, said that some modification of the policy of building nuclear stations 
in remote places was now possible. The minister was acting on advice given him by the Nuclear Safety Advisory Committee, which had said that the principal safeguard to public health came from the high standards of design, construction and operation of nuclear stations. For gas cooled reactors built in pre-stressed concrete vessels, it was clear that it was safe to build them much nearer to cities than had been customary. Mr Marsh said that this meant any area with a population density sufficiently light to evacuate the people within a range of 1.5 to 2 miles in the unlikely event of an accident. He agreed that this included the areas around Hartlepools and Heysham, both possible sites for nuclear stations.

The decision raises some interesting issues. Although most people agree that a relaxation of the restrictions is timely, particularly in Britain where isolated sites are hard to find, the decision of the committee refers only to British gas cooled reactors. What would happen if the generating boards decided to build a water reactor in the United States style (as they have sometimes threatened to do) is not made clear. A direct comparison of the safety of the two reactor types has not been made-so far both have a completely clean record, although it has been suggested that gas cooled reactors are inherently safer. The decision also clears the way for the generating boards to replace some of their older coal fired stations with nuclear stations, making better use of sites nearer to towns. As the map shows, all British nuclear stations so far built are in fairly remote areas, which has tended to increase the costs of building and of transmitting the power to the point of use.

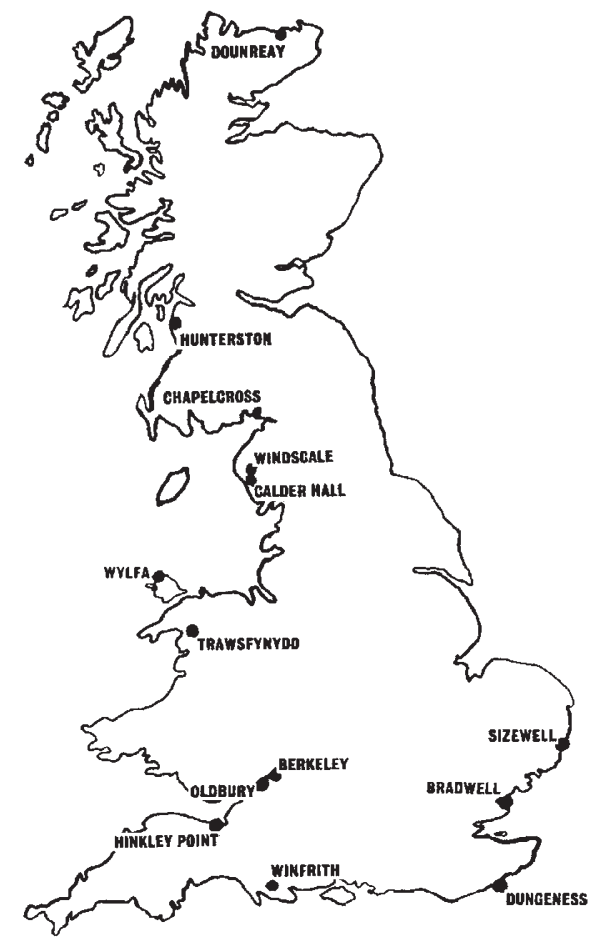

In other parts of the world which lack the sophisticated grid system in operation in Britain, the advantages of building near towns may be even greater. This, it is hoped, may help the export of British power stations, perhaps to Germany. As Mr Eric Lubbock mentioned in the short debate in the Commons, a power station is to be built near Ludwigshafen in West
Germany; Mr Marsh pointed out that another is to be built within 20 miles of Hamburg. The fact that Britain is now willing to build as near as this to towns will lend some weight to the tenders made by British consortia. In the United States, Consolidated Edison did once propose to build a station in New York, but were dissuaded by the Atomic Energy Commission. Despite this, the same tendency for generating stations to get ever nearer to towns has been observed in the United States. One of the problems which dictates a cautious advance, however, is the way in which the size of nuclear stations has increased. In this sense, Mr Marsh is disingenuous to claim that Britain has 132 nuclear years of experience. Until Dungeness $B$ starts operating, Britain has no actual experience of a commercial advanced gas cooled reactor. The experience is on the less sophisticated-and generally smaller-magnox reactors.

\section{Kidney Transplants}

THE ethical problems of transplanting organs are to be discussed at a conference announced on February 14 by Mr Kenneth Robinson, Minister of Health. The conference will be chaired by Sir Hector MacLennon, President of the Royal Society of Medicine, and will include lawyers, leading churchmen and laymen as well as doctors. Although the conference will be private, there seems some chance at least of a joint communiqué being issued after it is over. The ministry has emphasized that the purpose of the conference is to discuss the problems that have arisen in the provision of kidneys for transplant operations in Britain, and not to embark on lengthy discussions of the more controversial subject of heart transplants. So far, because there have been no heart transplant operations in Britain, the discussion of the subject has been less acrimonious than elsewhere, but there have already been signs of sharp disagreement. The minister will be hoping to steer the discussion away from such potentially dangerous topics.

Kidney transplantation is a much less heated subject; almost everybody agrees that in principle it is a very good thing. But technical difficulties over the provision of kidneys from donors have at times made the surgeon's task harder than it might have been. Some surgeons feel that the law should be amended so that kidneys could be taken from fatally injured people without consent from relatives. The difficulty here is that the kidney must be removed from the patient very soon after death if it is to be of any use to the patient.

\section{Guidance for Universities}

BRITISH universities have now been provided with some cautious guidance on the degree to which lecture rooms and laboratories are being used. This information is the first product of the work of the sub-committee under Mr C. F. Carter, Vice-Chancellor of the University of Lancaster, which has been brooding on the utilization of university facilities for the best part of a year. The report now being sent to universities is based on a survey in sixteen institutions which has been carried out by Mr K. S. Davies, the research officer attached to the project by the vice-chancellors? committee. At this stage it is clear that everybody is anxious not to let the universities feel that they are being coerced into a uniform pattern of teaching, and 